\title{
Antifertility Effects of Aqueous Roots Extract of Alchornea cordifolia (Euphorbiaceae) on Female Albino Rats
}

\author{
Dieudonne Massoma Lembè1, Larice E. Njoh Njoh1', Emma F. Bend1, Brice L. Koloko', \\ Pierre C. Oundoum Oundoum ${ }^{1}$, Marie I. Ngaha Njila1, Hubert Kenmogne ${ }^{1}$, \\ Cyprien M. Hambe'1, Marie C. Tchamadeu', Judith Domkam², Theophile Dimo², \\ Gustavo F. Gonzales ${ }^{3}$ \\ ${ }^{1}$ Department of Animal Sciences, Faculty of Science, University of Douala, Douala, Cameroon \\ ${ }^{2}$ Department of Animal Biology and Physiology, Faculty of Science, University of Yaounde I, Yaounde, Cameroon \\ ${ }^{3}$ Laboratory of Endocrinology and Reproduction, Faculty of Sciences and Philosophy Alberto Cazorla Talleri, \\ Universidad Peruana Cayetano Heredia, Lima, Peru \\ Email:pmasso@yahoo.fr
}

Received 1 June 2014; revised 3 July 2014; accepted 20 July 2014

Copyright (C) 2014 by authors and Scientific Research Publishing Inc.

This work is licensed under the Creative Commons Attribution International License (CC BY). http://creativecommons.org/licenses/by/4.0/

c) (i) Open Access

\section{Abstract}

Aqueous roots extract of Alchornea cordifolia was studied to evaluate its traditional antifertility claim. Antifertility effect of Alchornea cordifolia was evaluated according to the stages of pregnancy of female rats. In the first stage, forty female rats were randomly divided into four groups (10 rats/group) and respectively treated with $1 \mathrm{ml}$ distilled water (control), 100, 200 and $400 \mathrm{mg} / \mathrm{kg}$ body weight (BW) per day of Alchornea cordifolia. After laparotomy and at parturition, sites of implantation and resorption on the uterine horns were determined. The ovaries and uterus were collected and weighed. Blood samples were collected for hormonal assay. In the second and third stage of pregnancy, treatment schedule and antifertility parameters were assessed as above for the first stage. Treated groups received daily $400 \mathrm{mg} / \mathrm{kg} \mathrm{bw}$ of extract of Alchornea cordifolia while Control group received distilled water. It was observed in the first stage of pregnancy that, the number of resorption sites significantly $(p<0.05)$ decreased at 100 and $200 \mathrm{mg} / \mathrm{kg}$. No implantation site was observed at dose $400 \mathrm{mg} / \mathrm{kg}$ after laparotomy as well as the number of pups at parturition at all doses. The body weight of ovaries and uterine horns at dose $400 \mathrm{mg} / \mathrm{kg}$ significantly $(p<0.05)$ decreased when compared to the control. The extract dose dependently decreased significantly the concentrations of serum progesterone. In the second stage of pregnancy after laparotomy and at parturition, the number of live fetus and the survival ratio significantly $(p<0.001)$ decreased and were associated with the vaginal discharge and bleeding of animals. In the third stage of pregnancy, the extract caused an early parturition associated with a decreased number of live fetus and the survival ratio with $\mathrm{p}<\mathbf{0 . 0 0 1}$. The results indicate that aqueous roots extract of Alchornea cordi- 
folia could induce inhibitory effects on reproductive functions in female albino rats.

Keywords

Implantation, Embryo Development, Abortion, Hormone Level

\section{Introduction}

Population growth throughout the world more particularly in underdeveloped countries has tremendous effect on the economic progress. There is a global need to support individuals in family-planning due to the increasing growth rate of the world's population with its negative impact on environment as well as on social system. Although considerable progress has been made in the development of highly effective variety of synthetic contraceptive drugs, the most challenging pursuits in health care system is the search for newer, more potent, additional safe and less expensive methods that require self administration and can be available to the majority of population of any country. It is why traditional medicine has received considerable interest in the treatment of diseases in the third world population. Nearly $80 \%$ of the world populations rely on traditional medicines for primary health care, most of which involve the use of plant extracts [1]. Several studies for induction of infertility have been investigated over a long period including immunological, hormonal and chemical approaches [2]. Many plants' extract have been used as antifertility agents in folklore and traditional medicine without producing apparent toxic effects [3].

Alchornea cordifolia is a climbing shrub sometimes to $4 \mathrm{~m}$ tall. It is found in forest galleries, fresh soil, on the banks of the rivers and swamps in Senegal, Sierra Leone, Togo, Nigeria, Central African Republic and Cameroon [4]. Phytochemical investigation of Alchornea cordifolia plant showed the presence of secondary metabolites such as flavonoids [5], alkaloids, tannins and saponins [6]; sterols and terpenoids [7]. Alchornea cordifolia is used in traditional medicine as an abortifacient to treat malaria [8], diseases of the skin such as ulcers, the ringworm [9] and leprosy [10]. Therefore the present study was carried out to scientifically validate the claimed antifertility activity of the roots of this plant.

\section{Material and Methods}

\subsection{Plant Material}

Plant collection. The roots of Alchornea cordifolia were collected on April in the locality of Ebondi of the South region of Cameroon. The plant material was authenticated by Ghogue Jean Paul from the Botanic Department of University of Yaounde I. and a voucher specimen was deposited at the national herbarium under reference number Nana P 457; Surville 450.

Extracts preparation. The roots of Alchornea cordifolia was cut into small species and air dried. $4 \mathrm{~kg}$ of the powdered roots was suspended in $10 \mathrm{l}$ of distilled water, heated and boiled under reflux for $45 \mathrm{~min}$. After filtration by the Whatman No. 3 filter paper, the obtained decoction was stored at $-20^{\circ} \mathrm{C}$ for lyophilisation. The crude yield of the lyophilised material was approximately $31.04 \mathrm{~g}$. The lyophilised extract was further diluted to obtain different concentrations in $1 \mathrm{ml}$. Obtained solutions were kept at $4^{\circ} \mathrm{C}$ until further used.

Screening of the plant. According to the guidelines for the appropriate use of herbal medicines [11], four single different oral doses (1, 2, 4 and $5 \mathrm{~g} / \mathrm{kg}$ body weight) of extract of Alchornea cordifolia was given to four different groups of mice ( 5 per group) and observed $48 \mathrm{~h}$ later to determine any sign of toxicity. No toxic effect was observed during the period of the test (data not shown).

\subsection{Animals}

The experiment was performed with adult male and female Wistar rats at least 10 to 12 weeks of age and weighing between 190 - $220 \mathrm{~g}$. The animals were obtained from the Animal House at the University of Douala. The animals were allowed to acclimatize to the laboratory condition (temperature $24^{\circ} \mathrm{C}-28^{\circ} \mathrm{C}$ and $12 \mathrm{~h} \mathrm{light-}$ dark cycle) for two weeks before commencement of the experiment with free access to rat chow and water $\mathrm{ad}$ libitum throughout the study. The animals were weighed daily. Vaginal smears were taken daily and only female 
rats displaying at least two consecutive 4 days oestrous cycles were used. Anti fertility effect of Alchornea cordifolia was evaluated during the three stages of pregnancy of female rats. The first stage started from day 1 to day 7 of pregnancy; the second stage started from day 8 to day 14 of pregnancy and the third stage started from day 14 to day 21 of pregnancy. Ethics Committee of the Faculty of Science-Section, University of Douala approved the protocol for these experiments.

\subsection{Embryo Implantation and Teratogene Effects of Alchornea cordifolia}

Before the beginning of treatment, each female on proestrous stage was placed in the cage of proven fertile male breeders. The presence of vaginal plugs or the presence of sperm in the vaginal smear was taken as a successful copulation in female and this day was designated as day 1 of pregnancy. According to the females that were in proestrous stage, the ratio between male/female for mating did not exceed $1 / 3$. The dose used by traditional physicians to induce abortion is about 150 - $200 \mathrm{mg} / \mathrm{kg}$ for a person of $60-70 \mathrm{~kg}$ body weight. So in an attempt to further validate scientifically the traditional claims, forty female rats were randomly divided into four groups (10 rats/ group) GA, GB, GC and GD and respectively treated with $1 \mathrm{ml}$ distilled water (control), 100, 200 and $400 \mathrm{mg} / \mathrm{kg}$ body weight (BW) per day of Alchornea cordifolia during the first stage of pregnancy. Each group was divided into two subgroups (5 rats per subgroup) designated as $\mathrm{GA}_{1}$ and $\mathrm{GA}_{2} ; \mathrm{GB}_{1}$ and $\mathrm{GB}_{2} ; \mathrm{GC}_{1}$ and $\mathrm{GC}_{2} ; \mathrm{GD}_{1}$ and $\mathrm{GD}_{2}$.

On day 9, the four subgroups $\mathrm{GA}_{1}, \mathrm{~GB}_{1}, \mathrm{GC}_{1}$ and $\mathrm{GD}_{1}$ of rats were laparotomized under light ether anesthesia. Sites of implantation and resorption on the uterine horns were determined. The ovaries and uterus were collected and weighed. Blood samples were collected for hormonal assay. Serum progesterone levels were determined by ELISA using a commercial kit (Diagnostic Products Co. USA).

The rats of the subgroups $\mathrm{GA}_{2}, \mathrm{~GB}_{2}, \mathrm{GC}_{2}$ and $\mathrm{GD}_{2}$ were observed until parturition. After parturition, the number of pups (alive or dead) was counted; sites of fetal resorptions (if any) were recorded.

\subsection{Abortifacient Effect of Alchornea cordifolia}

Twenty Female rats were randomly divided into two groups (10 rats/group) GE and GF and respectively treated with $1 \mathrm{ml}$ distilled water (control) and $400 \mathrm{mg} / \mathrm{kg}$ body weight (BW) per day of Alchornea cordifolia during the second stage of pregnancy. Each group was divided into two subgroups (5 rats per subgroup) designated by $\mathrm{GE}_{1}$ and $\mathrm{GE}_{2} ; \mathrm{GF}_{1}$ and $\mathrm{GF}_{2}$.

On day 16 , the two subgroups $\mathrm{GE}_{1}$ and $\mathrm{GF}_{1}$ of rats were lapartomized under light ether anesthesia and the following parameters were recorded: vaginal discharge and bleeding; number of live and dead fetuses; \% survival ratio $=$ (number of live fetus/number of live + dead fetus $) \times 100$.

The female rats of the Sub group $\mathrm{GE}_{2}$ and $\mathrm{GF}_{2}$ were observed until parturition and the same parameters were recorded as above in laparotomized animals.

\subsection{Effect of Alchornea cordifolia on Parturition}

Ten Female rats were randomly divided into two groups (5 rats/group) GG and GH and respectively treated with $1 \mathrm{ml}$ distilled water (control) and $400 \mathrm{mg} / \mathrm{kg}$ body weight (BW) per day of Alchornea cordifolia during the third stage of pregnancy. At parturition, the following parameters were recorded: number of live and dead pups; \% survival ratio $=($ number of live pups/number of live + dead pups $) \times 100$.

\subsection{Statistical Analysis}

All statistical analysis was conducted using the Stat graphics Plus software (version 8.4. 2007). Results were expressed as mean \pm SEM (standard error of the mean). Differences between groups were assessed by one-way analysis of variance (ANOVA). Differences between pair of means were assessed by the Least Significant Difference (LSD) test. When variance was not homogeneous a non-parametric analysis of KRUSKAL-WALLIS and MANN-WHITNEY was performed. A value of $\mathrm{P}<0.05$ was considered as statistically significant.

\section{Results}

\subsection{Effects of Alchornea cordifolia on Implantation}

Administration of Alchornea cordifolia extract to the female rats significantly $(\mathrm{p}<0.05)$ decreased at dose 100 
and $200 \mathrm{mg} / \mathrm{kg}$ the number of resorption sites during the first stage of pregnancy. No implantation site was observed at dose $400 \mathrm{mg} / \mathrm{kg}$ as well as the number of pups at parturition at all doses Table 1 .

\subsection{Teratogene Effect of Alchornea cordifolia}

As it's described in Table 2, the extract did not alter the body weight of ovaries and uterine horns at dose 100 $\mathrm{mg} / \mathrm{kg}$ of treated animals. Nevertheless, at dose $400 \mathrm{mg} / \mathrm{kg}$ the weight of the two sexual organs significantly ( $<$ 0.05) decreased when compared to the control.

\subsection{Effects of Alchornea cordifoliaon Abortion}

During the second stage of pregnancy, administration of $400 \mathrm{mg} / \mathrm{kg}$ body weight of the extract after laparotomy and at parturition significantly $(\mathrm{p}<0.001$ ) decreased the number of live fetus respectively by $95.16 \%$ and $80 \%$. The survival ratio was respectively $8.33 \%$ and $47.62 \%$ for $400 \mathrm{mg} / \mathrm{kg}$ body weight of the extract-treated groups, as against $100 \%$ in the control animals. The effect of aqueous extract of Alchornea cordifolia resulted in $60 \%$ and $40 \%$ abortion, respectively, as indicated by the vaginal discharge and bleeding of animals during the laparotomy and at parturition (Table 3).

\subsection{Effects of Alchornea cordifoliaon Parturition}

Administration of $400 \mathrm{mg} / \mathrm{kg}$ body weight of the extract at the third stage of pregnancy caused an early parturition. Parturition occurred at day 18 of pregnancy. The Alchornea cordifolia aqueous extract significantly ( $\mathrm{p}<$ 0.001 ) decreased the number of live fetus by $42.86 \%$. The survival ratio was $75 \%$ when compared to the control animals. Vaginal bleeding was observed to $20 \%$ of treated animals (Table 4 ).

Table 1. Effects of Alchornea cordifolia on embryo implantation.

\begin{tabular}{cccc}
\hline Parameters & Doses (mg/kg b.wt) \\
\hline Resorption sites after laparoromy & Control & 100 & 200 \\
Number of pups at parturition & 0 & $10.4 \pm 0.24^{*}$ & 0 \\
0 & $11.8 \pm 0.37$ & 0 & 0 \\
\hline
\end{tabular}

Values are mean $\pm \mathrm{SE} ; \mathrm{n}=5{ }^{*} \mathrm{p}<0.05$ vs control; ${ }^{\mathrm{a}} \mathrm{p}<0.05$ vs $100 \mathrm{mg} / \mathrm{kg}$ bw.

Table 2. Effect of Alchornea cordifolia on the weight of ovaries and uterine horns.

\begin{tabular}{ccccc}
\hline Parameters & \multicolumn{4}{c}{ Doses (mg/kg b.wt) after laparotomy } \\
& Control & 100 & 200 & 400 \\
\hline Weight of uterine horns (g) & $1.600 \pm 0.003$ & $1.11 \pm 0.07$ & $1.01 \pm 0.22$ & $0.86 \pm 0.32^{*}$ \\
Weight of ovaries (g) & $0.2 \pm 0.04$ & $0.16 \pm 0.01$ & $0.07 \pm 0.01 *$ ab & $0.08 \pm 0.01^{* a}$ \\
\hline
\end{tabular}

Values are mean $\pm \mathrm{SE} ; \mathrm{n}=5 ;{ }^{*} \mathrm{p}<0.05$ vs control; ${ }^{\mathrm{a}} \mathrm{p}<0.001 \mathrm{vs} 100 \mathrm{mg} / \mathrm{kg} ;{ }^{\mathrm{b}} \mathrm{p}<0.001 \mathrm{vs} 100 \mathrm{mg} / \mathrm{kg}$.

Table 3. Abortifacient effects of Alchornea cordifolia.

\begin{tabular}{|c|c|c|c|c|}
\hline \multirow{3}{*}{ Parameters } & \multicolumn{4}{|c|}{ Doses (mg/kg b.wt) } \\
\hline & \multicolumn{2}{|c|}{ After laparotomy } & \multicolumn{2}{|c|}{ At parturition } \\
\hline & Control & 400 & Control & 400 \\
\hline Number of live fetus & $11.8 \pm 0.37$ & $0.6 \pm 0.6^{* * *}$ & $8.0 \pm 0.71$ & $2.0 \pm 0.94^{* * *}$ \\
\hline Number of dead fetus & 0 & $6.6 \pm 0.93$ & 0 & $2.2 \pm 0.97$ \\
\hline Survival ratio (\%) & 100 & 8.33 & 100 & 47.62 \\
\hline Vaginal discharge and bleeding (\%) & 0 & 60 & 0 & 40 \\
\hline
\end{tabular}

Values are mean $\pm \mathrm{SE} ; \mathrm{n}=5 ;{ }^{* * *} \mathrm{p}<0.001$ vs control. 


\subsection{Effects of Alchornea cordifolia on Progesterone Level}

The extract dose dependently decreased significantly the concentrations of serum progesterone (Figure 1).

\section{Discussion}

Several lines have suggested that some herbal drugs can be used as antifertility agents in mice, rats, rabbits and even humans [12] [13]. Although many reports have showed that the use of plant extract can affect reproductive physiology of the animal, there are no reports in the literature which evaluate the effect of Alchornea cordifolia extract on implantation and embryo development. Any plant's agents that can disrupt pregnancy can be used as a potential contraceptive and therefore could be of obvious interest in human fertility control [14]. In the present study, the absence of weight loss, appetite, diarrhea, as well as mortality in the extract-treated animals suggests that the extract was not clinically toxic to the female rats. We have noticed in the present work that, the day-to-day administration of the aqueous extract of the roots of Alchornea cordifolia at the first stage of gestation in female rats led affect implantation particularly at the dose of $400 \mathrm{mg} / \mathrm{kg}$ when compared to control. This effect of the aqueous extract of Alchornea cordifolia on implantation is marked by the presence of resorption sites through the uterine horns of rats sacrificed on the 8th day of gestation and by the absence of pups to those left to term. These results agree with those of Yakubu et al. (2010) [15] who observed a reduction in the number of embryonic implantation sites. It is known that, implantation takes place normally three to four days after fertilization in female rats [16], which suggests that administration of the aqueous extract of Alchornea cordifolia from the second day of gestation would have hindered the process of implantation at dose $100 \mathrm{mg} / \mathrm{kg}$ and 200 $\mathrm{mg} / \mathrm{kg}$ and even blocked it at dose $400 \mathrm{mg} / \mathrm{kg}$. The dose dependent decrease of resorption sites observed to the

Table 4. Effects of Alchornea cordifolia on parturition.

\begin{tabular}{cccc|}
\hline & \multicolumn{2}{c|}{ Doses (mg/kg b.wt) } \\
\hline Parameters & \multicolumn{2}{c|}{ Parturition at day 18} \\
\hline & Control & $3.6 \pm 1.03^{* * *}$ \\
\hline Number of live fetus & $9.0 \pm 0.31$ & $1.2 \pm 0.8$ \\
Number of dead fetus & 0 & 75 \\
Survival ratio (\%) & 100 & 20 \\
\hline
\end{tabular}

Values are mean $\pm \mathrm{SE} ; \mathrm{n}=5$.

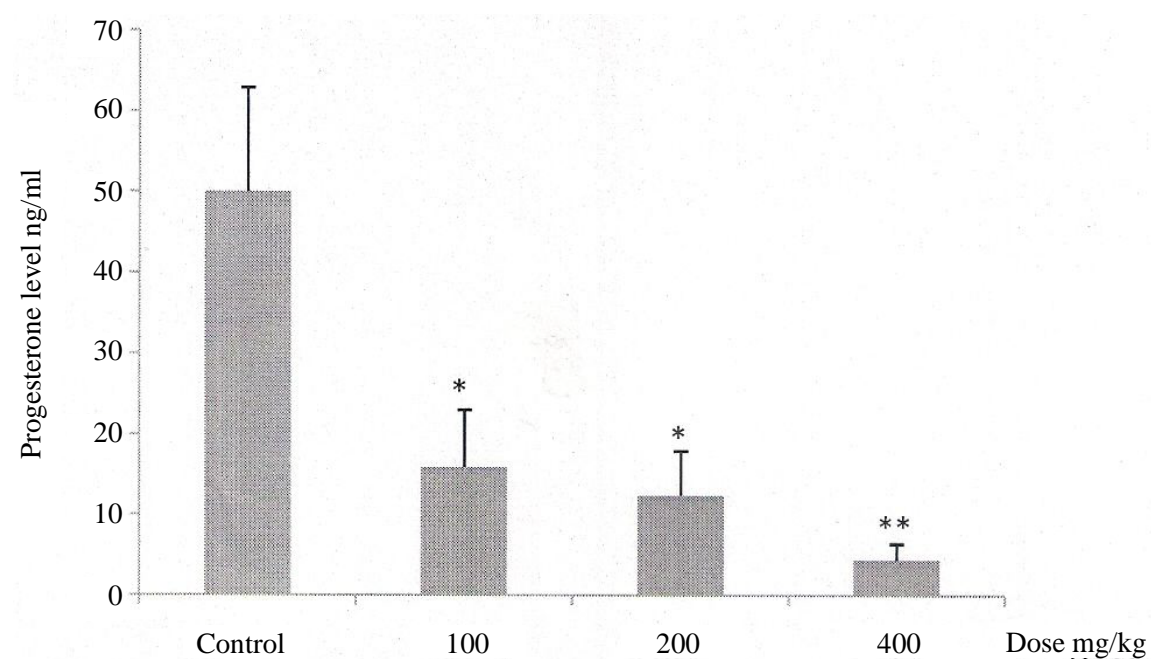

Figure 1. Effect of Alchornea cordifolia on progesterone level value are mean $\pm \mathrm{SE} ; \mathrm{n}=5$. ${ }^{*} \mathrm{p}<0.005$ vs control; ${ }^{* *} \mathrm{p}<0.01$ vs control. 
treated animal could be related to presence of alkaloids, uterine activity or hormonal disturbance. In fact, chemical agents can disrupt pregnancy possibly by interfering with the mitotic process of the embryo development then led in embryonic loss [17] [18]. It is likely that inactivation and poor placement of the blastocytes linked to uterine activity are harmful to embryo implantation [19]. Therefore, the decrease of the uterine weight by the extract is an indication of failure in the development of the embryo in this study. In the other hand, alkaloids have been used for centuries to induce abortion [20], the presence of these constituents in Alchornea cordifolia roots may be responsible for the abortifacient effect of the root extract. In addition, Spencer et al. (2004) [21] suggested that this decrease in the number of implantation sites could be in relation with the variation of some hormonal effects. It is well known that for implantation exact equilibrium of estrogen and progesterone is essential, any disturbance in level of these hormones causes infertility [15]. It has been also reported that during pregnancy, blood levels of progesterone increases for the maintenance of conditions for the process of settlements and the development of the fetus. Thus, its decrease may cause adverse effects such as: the embryonic resorption, abortion, and inhibition of implantation [22] [23]. On the other hand, Hiremath et al. (1990) [24] have shown that the regular development of the whole of events leading at least for implantation in female rats (first stage of gestation) is mainly under the direct command of the estrogen-progesterone interaction at the cellular level. Thus any slight disruption of this hormonal balance can cause a malfunction of the endometrium. Our results have shown that the administration of the aqueous extract of Alchornea cordifolia at the early stage of gestation resulted in a decrease in serum levels of progesterone, which would be responsible for the resorption of embryos and therefore, the total absence of implantation at high doses.

Phytoestrogens are known to develop excessive numbers of small and medium sized ovarian follicles in many of which antrum formation was deficient. This was associated with early atresia of the follicles. In addition, the uterine submucosa and muscle layer were oedematous and subacute endometritis was present [25]. Some researchers showed that, phytoestrogens may also lead to reduced ovarian weight with hemorrhage [26], low birth rates, uterine prolapsed, hydrops uteri and pyometron, thereby reducing ovulation and conception rates [27]. On the other hand, previous reports indicate the presence of flavonoids [28], alkaloids [29], saponin [30] and terpenoids [31] in medicinal plants with contraceptive or pregnancy interceptory effects. Therefore, the presence of steroids and one or more of these chemical agents in Alchornea cordifolia roots may be responsible for the abortifacient and pregnancy-terminating effect of the roots extract on the second stage of pregnancy of female rats. Since chemical insults both before and after the implantation process can result in pre- and postimplantation embryonic loss [18], it is then clear that, the increase in the number of dead fetus as well as reduced survival ratio after laparotomy and at parturition in this stage of pregnancy, suggest a potent abortifacient activity of aqueous extract of Alchornea cordifolia at dose $400 \mathrm{mg} / \mathrm{kg}$. We have to notice that, the decrease of the weight of uterus with the presence of phytoestrogens in this study may be due to chemical interactions that produce alterations in the uterine milieu and create hostile conditions in the uterus [32]. It is these chemical components, when given at the third stage of pregnancy that induced early parturition to female rats associated with high survival ratio. This indicates that the aqueous roots extract of Alchornea cordifolia is less toxic when it administrated in late period of pregnancy. These chemical compounds could act synergistically causing the death of the foetus, abortion and vaginal bleeding in treated female rats.

\section{Conclusion}

The results suggest that aqueous roots extract of Alchornea cordifolia could induce inhibitory effects on reproductive functions in female albino rats. This study thus justifies the folkloric claim of the aqueous extract of Alchornea cordifolia roots as an abortifacient.

\section{References}

[1] Sandhya, B., Thomas, S., Isabel, W. and Shenbagarathai, R. (2006) Ethnomedicinal Plants Used by the Valaiyan Community of Piranmalai Hills (Reserved Forest), Tamil Nadu, India. A Pilot Study. The African Journal of Traditional, Complementary and Alternative Medicines, 3, 101-114.

[2] Gupta, R.S. and Rakhi, S. (2006) A Review on Medicinal Plant Exhibiting Antifertility Activity on Males. Indian Journal of Natural Products and Resources, 5, 389-410.

[3] Singh, A. and Singh, S.K. (2009) Evaluation of Antifertility Potential of Brahmi in Male Mouse. Contraception, 79, 71-79. http://dx.doi.org/10.1016/j.contraception.2008.07.023 
[4] Arbonnier (2002) Arbres, arbustes et lianes des zones sèches d'Afrique de l’Ouest. CIRAD, MNHN.

[5] Ogungbamila, F.O. and Samuelsson, G. (1990) Flavonoïdes de détente de muscles lisse de Alchornea cordifolia. Acta Pharmaceutica, 2, 421-422.

[6] Osadebe, P.O. and Okoye, F.B. (2003) Les Effets Anti-Inflammatoires de l'extrait méthanolique brut et de fractions de feuilles de Alchornea cordifolia. Journal of Ethnopharmacology, 89, 19-24. http://dx.doi.org/10.1016/S0378-8741(03)00195-8

[7] Ajali, U. (2000) Activité antibactérienne d'ecorces de tige de Alchornea cordifolia. Fitotérapia, 4, 436-438. http://dx.doi.org/10.1016/S0367-326X(00)00131-3

[8] Mustofa Valentin, A., Benoit-Vical, F., Pelissier, Y., Kone-Bamba, D. and Malli, M. (2000) Activité d'Antiplasmodiale des extraits d'usines utilisés dans la médecine traditionnelle Africaine occidentale. Journal of Ethnopharmacology, 73, 145-151.

[9] Kerharo, J. and Bouquet, A. (1950) Plantes médicinales et toxique de la côte d’Ivoire. Haute Volta, Edition Vigot, 67.

[10] Abbiw, D.K. (1990) Useful Plants of Ghana, Royal Botanique Garden. Kew Edition, 126-247.

[11] WHO (1998) Guinelines for the Appropriate Use of Herbal medecines. Regional Office for Western Pacific, Manila, 65.

[12] Kazerooni, T., Mousavizadeh, K., Abdollahee, A., Sarkarian, M. and Sattar, A. (2006) Abortifacient Effect of Prangos ferulacia on Pregnant Rats. Contraception, 73, 554-556. http://dx.doi.org/10.1016/j.contraception.2005.11.001

[13] Koneri, R., Saraswati, C.D., Balaraman, R. and Ajeesha, E.A. (2007) Antiimplantation Activity of the Ethanolic Root Extract of Momordica cymbalaria Fenzl in Rats. Indian Journal of Pharmacology, 39, 90-96. http://dx.doi.org/10.4103/0253-7613.32527

[14] Goonasekera, M.M., Gunawardana, V.K., Jayasena, K., Mohammed, S.G. and Balasubramaniam, S. (1995) Pregnancy Terminating Effect of Jatrophacurcas in Rats. Journal of Ethnopharmacology, 47, 117-123. http://dx.doi.org/10.1016/0378-8741(95)01263-D

[15] Yakubu, M.T., Olawepo, O.J. and Fasoranti, G.A. (2011) Ananascomosus: Is the Unripe Fruit Juice an Abortifacient in Pregnant Wistar Rats? The European Journal of Contraception and Reproductive Health Care, 16, 397-402. http://dx.doi.org/10.3109/13625187.2011.599454

[16] Vaissaire, J.P. (1977) Appareil génital Femelle. In: Vaissaire, J.P., Ed., Sexualité et reproduction des Mammifères domestiques et de laboratoires, Maloine S.A., Paris, 23-51.

[17] Goonasekera, M.M., Gunawardana, V.K., Jayasena, K., Mohammed, S.G. and Balasubramaniam, S. (1995) Pregnancy Terminating Effect of Jatropha curcas in Rats. Journal of Ethnopharmacology, 47, 117-123. http://dx.doi.org/10.1016/0378-8741(95)01263-D

[18] Elbetieha, A., Oran, S.A., Alkofahi, A., Darmani, H. and Raies, A.M. (2000) Fetotoxic Potentials of Globularia arabica and Globularia alypum (Globulariaceae) in Rats. Journal of Ethnopharmacology, 72, 215-219. http://dx.doi.org/10.1016/S0378-8741(00)00246-4

[19] Chen, Q., Zhang, Y., Lu, J., Wang, Q., Wang, S. and Cao, Y. (2009) Embryo-Uterine Cross-Talk during Implantation: The Role of Wnt Signaling. Molecular Human Reproduction, 15, 215-221.

[20] Elderfied, R.C. (1980) Biographical Memoir for Walter Abraham Jacobs, 51. National Academy of Science, Washington DC, 247-278.

[21] Spencer, T.E., Johnson, G.A., Burghardt, R.C. and Bazer, F.W. (2004) Progesterone and Placental Hormone Actions on the Uterus: Insights from Domestic Animals. Biology of Reproduction, 71, 2-10.

[22] Yakubu, M.T. and Bukoye, B.B. (2009) Abortifacient Potential of the Aqueous Extract of Bambusa vulgaris Leaves in Pregnant Dutch Rabbits. Contraception, 80, 308-313. http://dx.doi.org/10.1016/j.contraception.2009.03.003

[23] Azadeh, M., Maryam, P., Mozafar, K. and Rostam, G. (2007) Anti-Fertility Effects of Physalis alkekengi Alcoholic Extract in Female Rat. Iranian Journal of Reproductive Medicine, 5, 13-16.

[24] Hiremath, S.P. and Harumantha, R.S. (1990) Antifertility Activity of Striga lutea (Scrophulariaceae) on Rats. Contraception, 42, 466-477.

[25] Adams, N.R. (1977) Morphological Changes in the Organs of Ewes Grazing Oestrogenic Subterranean Clover. Research in Veterinary Science, 22, 216-221.

[26] El-Samannoudy, F.A., Shareha, A.M., Ghannudi, S.A., Gillaly, G.A. and El-Mougy, S.A. (1980) Adverse Effects of Phytoestrogens-7. Effect of $\beta$-Sitosterol Treatment on Follicular Development, Ovarian Structure and Uterus in the Immature Female Sheep. Cellular and Molecular Biology, 26, 255-266.

[27] Adams, N.R. (1995) Detection of the Effects of Phytoestrogens on Sheep and Cattle. Journal of Animal Science, 73, 1509-1515. 
[28] Hiremath, S.P., Rudresh, K., Badami, S., Patil, S.B. and Patil, R.S. (1999) Post-Coital Antifertility Activity of Acalypha indica L. Journal of Ethnopharmacology, 67, 253-258. http://dx.doi.org/10.1016/S0378-8741(98)00213-X

[29] Ravichandra, V., Suresh, B., Satishkumar, M.N., Elango, K. and Srinivasan, R. (2007) Antifertility Activity of Hydroalcoholic Extract of Ailanthus excelsa (Roxb): An Ethno Medicine Used by Tribes of Nilgiris Region in Tamilnadu. Journal of Ethnopharmacology, 112, 189-191. http://dx.doi.org/10.1016/j.jep.2007.01.024

[30] Zanwar, A.A., Aswar, U.M., Hegde, M.V. and Bodhankar, S.L. (2010) Estrogenic and Embryo-Fetotoxic Effects of Ethanol Extract of Linum usitatissimum in Rats. Journal of Complementary and Integrative Medicine, 7, 1-17.

[31] Uchendu, C.N., Kamalu, T.N. and Asuzu, I.U. (2000) A Preliminary Evaluation of Antifertility Activity of a Triterpenoid Glycoside (DSS) from Dalbergia saxatilis in Female Wistar Rats. Pharmacological Research, 41, 521-525. http://dx.doi.org/10.1006/phrs.1999.0615

[32] Koneri, R., Saraswati, C.D., Balaraman, R. and Ajeesha, E.A. (2007) Antiimplantation Activity of the Ethanolic Root Extract of Momordica cymbalaria Fenzl in Rats. Indian Journal of Pharmacology, 39, 90-96.

http://dx.doi.org/10.4103/0253-7613.32527 
Scientific Research Publishing (SCIRP) is one of the largest Open Access journal publishers. It is currently publishing more than 200 open access, online, peer-reviewed journals covering a wide range of academic disciplines. SCIRP serves the worldwide academic communities and contributes to the progress and application of science with its publication.

Other selected journals from SCIRP are listed as below. Submit your manuscript to us via either submit@scirp.org or Online Submission Portal.
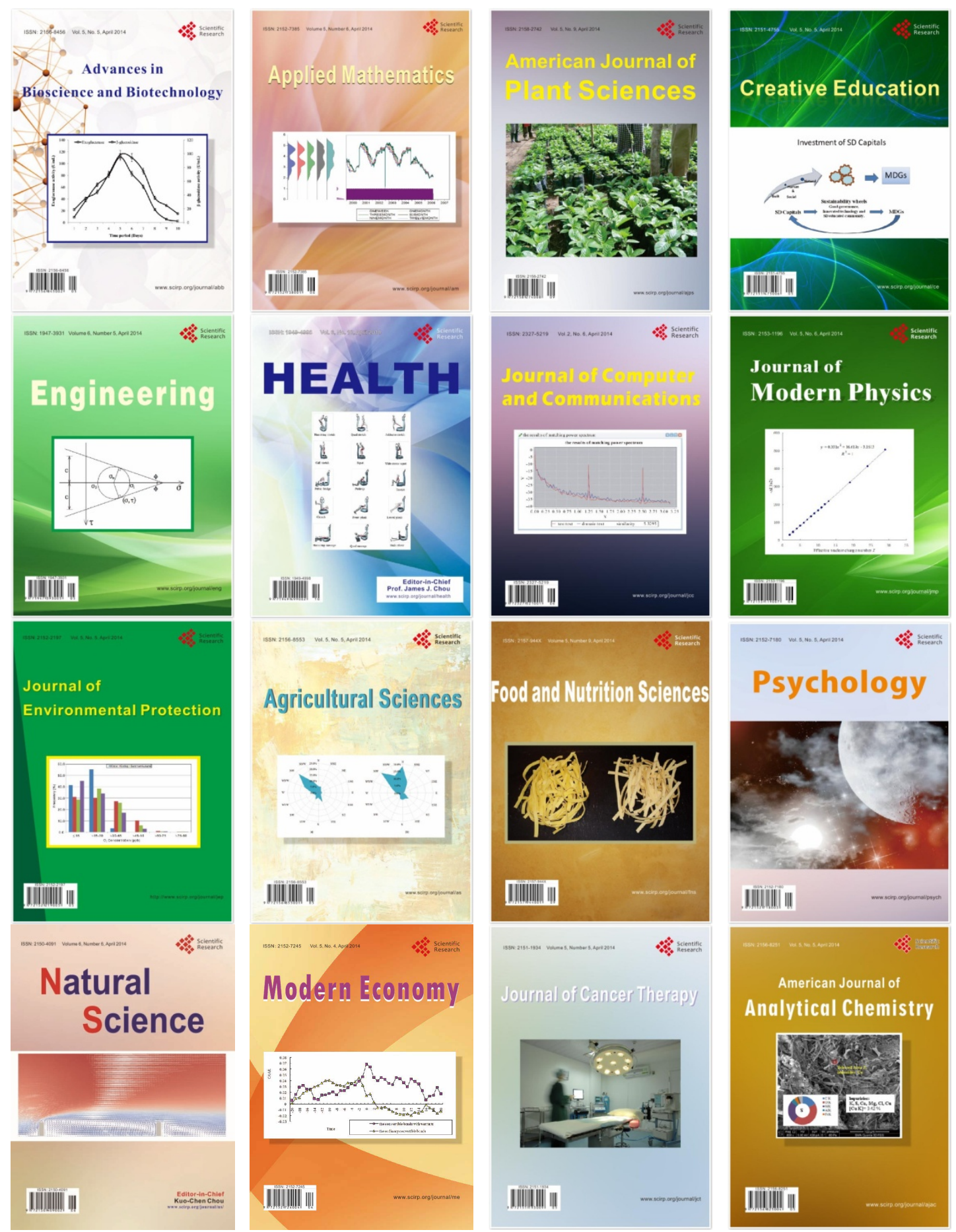